\title{
Alleviation of aluminum and cadmium toxicity by biochar and its potential toxicity to sorghum
}

\section{Mitigação da toxidez por alumínio e cádmio por biochar e seu potencial tóxico para o sorgo}

\author{
Jane Bruna de Almeida ${ }^{1}$; Laura Souza Santos ${ }^{1}$; Sugandha Dogra Pandey ${ }^{2}$; \\ Claudineia Ferreira Nunes ${ }^{3}$; Fernando Colen²; Regynaldo Arruda Sampaio²; \\ Leidivan Almeida Frazão ${ }^{2}$; Rodinei Facco Pegoraro ${ }^{3}$; Luiz Arnaldo Fernandes ${ }^{3^{*}}$
}

\begin{abstract}
Highlights:
Use of biochar to mitigate soils contaminated by trace elements. Pyrolysis as an alternative to sewage sludge disposal in the environment. Some mechanisms involved in the alleviation of soil acidity by biochar. A rapid and simple test to assess biochar toxicity. Biochar as a strong and effective sorbent for aluminum and cadmium.
\end{abstract}

\begin{abstract}
Biochar has been used as an alternative in organic wastes management and to alleviate trace elements toxicity. The aim of this research was to use a rapid and simple test to detect the potential toxic effects of biochar and its ability to alleviate aluminum and cadmium toxicity to seeds and seedlings of Sorghum bicolor L. Two experiments were carried out in Petri dishes with two different biochars where sorghum seeds were exposed to aluminum (experiment 1) and cadmium (experiment 2) solutions. The experimental designs were completely randomized, with five doses of aluminum or cadmium in aqueous solution $(0,0.5,1,2$, and $4 \mathrm{mmol} / \mathrm{L}$ of $\mathrm{Al}$ or $\mathrm{Cd})$, combined with or without the addition of $0.25 \mathrm{~g}$ of biochar from sugarcane bagasse or from sewage sludge. Compared to treatments without biochar, in the treatments with biochar, higher seed germination rate and growth of sorghum seedlings were obtained. Moreover, the biochars were not toxic to sorghum and they decreased the toxicity of aluminum and cadmium, mainly the biochar from sewage sludge that presented higher $\mathrm{pH}$ and greater occurrence of functional groups in its particles.
\end{abstract}

Key words: Trace elements. Heavy metals. Soil acidity. Pyrolysis. Organic wastes.

\section{Resumo}

O biochar tem sido utilizado como uma alternativa para o manejo de resíduos orgânicos e na remedição da toxidez por elementos traços. Objetivou-se com essa pesquisa usar um teste rápido e simples para detectar os potenciais efeitos tóxicos do biochar e sua capacidade de minimizar a toxidez por alumínio e cádmio para sementes e plântulas de Sorghum bicolor L. Conduziu-se dois experimentos em placas de

1 Discentes, Pós-Graduação em Produção Vegetal, Universidade Federal de Minas Gerais, UFMG, Montes Claros, MG, Brasil. E-mail: janebruna6@hotmail.com; laurasouzas02@yahoo.com.br

2 Pós-Doutoranda, UFMG, Belo Horizonte, MG, Brasil. E-mail: sugandha.dogra@gmail.com

3 Profs., UFMG, Montes Claros, MG, Brasil. E-mail: claudineia.f.nunes@gmail.com; fernandocolenufmg@gmail.com; regynaldo@terra.com.br; leidivan.frazao@gmail.com; rodinei_pegoraro@yahoo.com.br; luizmcmg@gmail.com

* Author for correspondence 
Petri com dois diferentes biochars onde as sementes de sorgo foram expostas às soluções de alumínio (experimento 1) e cádmio (experimento 2). Os delineamentos experimentais foram inteiramente casualizados, com cinco doses de alumínio ou cádmio na solução aquosa $(0,0,5,1,2$ e 4 mmol L-1 de $\mathrm{Al}$ ou $\mathrm{Cd}$ ), combinados com ou sem a adição de $0,25 \mathrm{~g}$ de biochar de bagaço de cana-de-açúcar (BB) ou de lodo de esgoto (BS). Nos tratamentos com biochar, obtém-se maior percentagem de germinação de sementes e crescimento de plântulas de sorgo em relação a ausência de biochar. Além disso, os biochars não são tóxicos para o sorgo e minimizam a toxicidade por alumínio e cádmio, principalmente o BS que apresenta maior $\mathrm{pH}$ e maior ocorrência de grupos funcionais em suas partículas.

Palavras-chave: Sorghum bicolor. Elementos traços. Acidez do solo. Pirólise. Resíduos orgânicos.

\section{Introduction}

Sorghum is a C4 plant widely used as a forage crop and it is the fifth most important cereal in the world (Soudek, Petrová, Vaňková, Song, \& Vaněk, 2014). In the Brazilian Savannah region, this species is widely used for forage production owing to its greater tolerance to drought and heat than the corn crop. Although it is a relatively hardy cereal, sorghum yields are significantly reduced by aluminum stress, resulting in a poorly developed root system that makes the crop vulnerable to drought and limits nutrient uptake (Samac \& Tesfaye, 2003).

To solve the problem of both aluminum toxicity and the disposal of organic waste in the environment, an alternative is the use of biochar as a soil conditioner (Penido et al., 2019). The transformation of sewage sludge into biochar eliminates pathogenic microorganisms, significantly reduces the volume of waste, and incorporates a more recalcitrant carbon source into the soil (Paz-Ferreiro, Nieto, Mendez, Askeland, \& Gasco, 2018). Although biochars from sewage sludge may have high concentrations of trace elements, sorghum plants are relatively tolerant to high cadmium concentrations in the growing environment (Soudek et al., 2014).

Biochar is a solid material, rich in carbon, resulting from the pyrolysis of organic waste (Lehmann \& Joseph, 2015). The use of biochar in agriculture or in remediation of soils contaminated by trace elements is justified by recycling large quantities of organic waste (Abdelhafez et al., 2014) and reducing the contamination associated with such waste (Gwenzi, Chaukura, Mukome,
Machado, \& Nyamasoka, 2015; Waqas et al., 2015; Ahmad et al., 2014).

In the remediation of soils contaminated by trace elements, biochar is considered a strong and effective sorbent owing to its high aromaticity and surface area, with the potential to reduce pollutant bioavailability (Chai et al., 2012). However, some sewage sludge might have high concentrations of trace elements and other contaminants and even after pyrolysis, they may remain in the derived biochar (Paz-Ferreiro et al., 2018; Kim, Ok, Choi, \& Park, 2015).

According to Solaiman, Murphy and Abbott (2012), there have been few studies reporting the influence of biochar on seed germination and seedling growth. In addition, an experiment in the Petri dish is a rapid eco-toxicological test for preliminary assessment of biochars. The objective of this work was to use a rapid and simple test to detect the potentially toxic effects of biochar and its ability to alleviate aluminum and cadmium toxicity to plants.

\section{Materials and Methods}

Two experiments were carried out in Petri dishes with two different biochars where sorghum seeds were exposed to aluminum (experiment 1) and cadmium (experiment 2) solutions. For both experiments, the methodology described by Soudek, Rodriguez Valesca, Petrová, Song and Vaněk (2016) was used to evaluate the toxicity of heavy metals in seed germination. 
The experimental designs were completely randomized, with five doses of aluminum (experiment 1) and cadmium (experiment 2) in the aqueous solution $\left(0,0.5,1,2\right.$, and $4 \mathrm{mmol} \mathrm{L}^{-1}$ of $\mathrm{Al}$ or $\mathrm{Cd})$, combined with or without the addition of $0.25 \mathrm{~g}$ of biochar from sugarcane bagasse $(\mathrm{BB})$ and sewage sludge (BS), with seven replicates. In each Petri dish of $10 \mathrm{~cm}$ diameter (experimental unit), ten sorghum seeds (Sorghum bicolor L.) were packed, filled with specific paper to test seed germination, and moistened with $5 \mathrm{~mL}$ of aqueous solution with $\mathrm{Al}$ or $\mathrm{Cd}$ doses, with or without biochar.

The Petri dishes containing seeds with different doses of $\mathrm{Al}$ or $\mathrm{Cd}$ and $\mathrm{BS}$ or BB were covered with plastic film and kept in a germination and growth Biological Oxygen Demand type chamber at $25 \pm$ $1{ }^{\circ} \mathrm{C}$ in the absence of light for ten days. After this period of ten days in the dark, the Petri dishes were placed in an environment with artificial light and on the 14th day, the number of germinated seeds and normal seedlings per Petri dish were evaluated and the abnormal seedlings were eliminated. On the 20th day after the experiment setup, the normal seedlings were separated into shoot and roots and oven-dried at $65^{\circ} \mathrm{C}$ for the determination of the dry matter.

The sludge was obtained after sewage processing using the following procedures: biological oxidation, sedimentation, and centrifugation treatments. The sugarcane bagasse was obtained after mechanical extraction of the juice. Sewage sludge biochar (BS) and sugarcane bagasse biochar (BB) were produced by slow pyrolysis and the temperature was elevated at a rate of approximately $5{ }^{\circ} \mathrm{C} /$ min until $450{ }^{\circ} \mathrm{C}$ for $\mathrm{BS}$, and until $350{ }^{\circ} \mathrm{C}$ for $\mathrm{BB}$ (temperature was controlled by a thermocouple inserted in the center of the carbonized mass) with a residence time of $30 \mathrm{~min}$.

The biochars were ground and passed through a $0.5 \mathrm{~mm}$ mesh sieve and collected using another $0.0635 \mathrm{~mm}$ mesh sieve for further experiments and characterization. Biochar yield was estimated by the ratio between pyrolyzed biochar (dry weight) and unpyrolyzed feedstock (dry mass). The electrical conductivity, pH, Cation Exchange Capacity (CEC), bulk density, and moisture content were calculated using methods described by Rajkovich et al. (2012) and ash content was measured using the D176284 procedure (American Society for Testing and Materials [ASTM], 2013).

Total $\mathrm{C}$ and $\mathrm{N}$ were determined using an elemental analyzer. Nutrients and trace elements were determined via ICP-MS/MS, after microwave digestion with concentrated nitric acid using the method 3051 (United States Environmental Protection Agency [USEPA], 2007). The ICP performance for trace elements analysis was verified using protocols from the National Institute of Standards and Technology (NIST), Standard Reference Material (SRM) 1640 in water, and the reference material (LPC1-100/500) from SPEX.

Fourier transform infrared spectroscopy (FTIR) analysis was performed between $4000-400 \mathrm{~cm}^{-1}$, with 64 scans per sample and a resolution of $2 \mathrm{~cm}^{-1}$ with the $\mathrm{KBr}$ pressed-pellet technique by mixing 1 $\mathrm{mg}$ of dried biochar with $100 \mathrm{mg}$ of pre-dried and pulverized spectroscopic-grade $\mathrm{KBr}$.

The data are presented as the means \pm confidence interval ( $t$-tests, $p<0.05)$. In the figures, vertical bars indicate the confidence interval for the mean.

\section{Results and Discussion}

The biochar from sewage sludge (BS) had significantly higher $\mathrm{pH}$, density, and $\mathrm{CEC}$ than the biochar from BB (Table 1). The higher $\mathrm{pH}$ of $\mathrm{BS}$ is correlated with its ash content as ash is rich in alkali metal oxides and hydroxides (Silva et al., 2017; Glaser, Lehmann, \& Zech, 2002; Steenari, Karlsson, \& Lindqvist, 1999), while the CEC can be explained by peaks of functional groups (Tang, Zhu, Kookana, \& Katayama, 2013) (Figure 1). In contrast, BB presented higher yield and total carbon and lower total nitrogen (Table 1). Feedstock like sugarcane bagasse present long-chain carbon compounds 
(such as lignin and cellulose) and usually produce biochars with higher yield and total carbon content (Lee et al., 2013). In addition, biochars generally present organic carbonaceous phases, like H, C,
$\mathrm{N}, \mathrm{O}$, and $\mathrm{S}$, rich in surface functional groups that contribute to the high $\mathrm{pH}$, cation exchange capacity, and surface complexation for trace elements

(Mukherjee, Zimmerman, \& Harris, 2011).

\section{Table 1}

Characterization of biochar from sewage sludge (BS) and from sugarcane bagasse (BB). Values represent the means \pm confidence interval $(t$ tests, $\mathrm{p}<0.05) . \mathrm{n}=4$

\begin{tabular}{|c|c|c|c|c|c|}
\hline Characteristic & $\mathrm{BS}$ & $\mathrm{BB}$ & Characteristic & $\mathrm{BS}$ & BB \\
\hline Yield (\%) & $47 \pm 3.2$ & $59 \pm 1.8$ & $\mathrm{Mg}\left(\mathrm{mg} \mathrm{kg}^{-1}\right)$ & $263 \pm 15.6$ & $5,6 \pm 67.4$ \\
\hline $\mathrm{pH}$ & $7.0 \pm 0.3$ & $6.5 \pm 0.2$ & $\mathrm{Fe}\left(\mathrm{mg} \mathrm{kg}^{-1}\right)$ & $29.9 \pm 2.5$ & $2,3 \pm 45.8$ \\
\hline $\mathrm{EC}\left(\mathrm{mS} \mathrm{cm} \mathrm{cm}^{-1}\right)$ & $0.99 \pm 0.13$ & $0.90 \pm 0.05$ & $\mathrm{Ba}\left(\mathrm{mg} \mathrm{kg}^{-1}\right)$ & $320 \pm 19.4$ & $27.9 \pm 2.1$ \\
\hline Density $\left(\mathrm{g} \mathrm{cm}^{-3}\right)$ & $0.60 \pm 0.21$ & $0.28 \pm 0.02$ & $\mathrm{Al}\left(\mathrm{mg} \mathrm{kg}^{-1}\right)$ & $2.0 \pm 0.5$ & $0.18 \pm 0.04$ \\
\hline Porosity (\%) & $68.8 \pm 7.9$ & $75.3 \pm 4.6$ & $\mathrm{Zn}\left(\mathrm{mg} \mathrm{kg}^{-1}\right)$ & $187 \pm 8.3$ & $26 \pm 3.6$ \\
\hline Ashes (\%) & $59 \pm 4.8$ & $30 \pm 2.9$ & $\operatorname{Mn}\left(\mathrm{mg} \mathrm{kg}^{-1}\right)$ & $466 \pm 17.4$ & $84 \pm 5.7$ \\
\hline $\mathrm{CEC}\left(\mathrm{mmol} \mathrm{kg}{ }^{-1}\right)$ & $336 \pm 12.4$ & $208 \pm 8.3$ & $\mathrm{Cu}\left(\mathrm{mg} \mathrm{kg}^{-1}\right)$ & $456 \pm 9.5$ & $145 \pm 11.4$ \\
\hline Total $\mathrm{C}\left(\mathrm{g} \mathrm{kg}^{-1}\right)$ & $156.7 \pm 16.3$ & $283 \pm 9.5$ & $\mathrm{Cr}\left(\mathrm{mg} \mathrm{kg}^{-1}\right)$ & $31.8 \pm 1.5$ & $<0.001$ \\
\hline Total N $\left(\mathrm{g} \mathrm{kg}^{-1}\right)$ & $26.8 \pm 3.2$ & $12.3 \pm 1.3$ & $\mathrm{Ni}\left(\mathrm{mg} \mathrm{kg}^{-1}\right)$ & $6.0 \pm 0.5$ & $0.03 \pm 0.01$ \\
\hline $\mathrm{C} / \mathrm{N}$ & 5.8 & $23.1 \pm 2.8$ & $\mathrm{Cd}\left(\mathrm{mg} \mathrm{kg}^{-1}\right)$ & $<0.001$ & $<0.001$ \\
\hline $\mathrm{P}\left(\mathrm{g} \mathrm{kg}^{-1}\right)$ & $240 \pm 14.5$ & $23.2 \pm 1.6$ & $\mathrm{~Pb}\left(\mathrm{mg} \mathrm{kg}^{-1}\right)$ & $<0.001$ & $<0.001$ \\
\hline $\mathrm{K}\left(\mathrm{g} \mathrm{kg}^{-1}\right)$ & $4.08 \pm 0.8$ & $4.3 \pm 0.6$ & As $\left(\mathrm{mg} \mathrm{kg}^{-1}\right)$ & $0.43 \pm 0.06$ & $0.05 \pm 0.03$ \\
\hline $\mathrm{S}\left(\mathrm{g} \mathrm{kg}^{-1}\right)$ & $6.39 \pm 19.5$ & $1.2 \pm 0.4$ & $\mathrm{Hg}\left(\mathrm{mg} \mathrm{kg}^{-1}\right)$ & $<0.001$ & $<0.001$ \\
\hline $\mathrm{Na}\left(\mathrm{mg} \mathrm{kg}^{-1}\right)$ & $449 \pm 12.9$ & $0.53 \pm 0.02$ & $\operatorname{Mo}\left(\mathrm{mg} \mathrm{kg}^{-1}\right)$ & $<0.001$ & $<0.001$ \\
\hline $\mathrm{Ca}\left(\mathrm{mg} \mathrm{kg}^{-1}\right)$ & $362 \pm 13.4$ & $18,200 \pm 98.4$ & $\mathrm{Se}\left(\mathrm{mg} \mathrm{kg}^{-1}\right)$ & $<0.001$ & $<0.001$ \\
\hline
\end{tabular}



Figure 1. Sorghum seedlings grown in medium without biochar (A), in medium with biochar from sewage sludge (B) and in medium with biochar from sugarcane bagasse (C). 
Organic and inorganic contaminants and pathogenic organisms are the main limiting factors for the agricultural use of sewage sludge and derived products (Resolução № 375, 2006). The BS had higher nutrients and trace elements than $\mathrm{BB}$, but the concentrations were considered lower than the respective maximum values established by Brazilian legislation (Resolução № 375, 2006) for sewage sludge and derived products for agriculture use: $\mathrm{Ba}, 1300 \mathrm{mg} \mathrm{kg}^{-1} ; \mathrm{Zn}, 2800 \mathrm{mg} \mathrm{kg}^{-1}$; Cu, 1500 mg kg-1 $; \mathrm{Cr}, 1000 \mathrm{mg} \mathrm{kg}^{-1} ; \mathrm{Ni}, 420 \mathrm{mg} \mathrm{kg}^{-1} ; \mathrm{Cd}, 39$ mg kg-1; $\mathrm{Pb}, 300 \mathrm{mg} \mathrm{kg}^{-1}$, As, $41 \mathrm{mg} \mathrm{kg}^{-1} ; \mathrm{Hg}, 17$ $\mathrm{mg} \mathrm{kg}{ }^{-1}$; Mo, $50 \mathrm{mg} \mathrm{kg}^{-1}$; and Se, $100 \mathrm{mg} \mathrm{kg}^{-1}$. It should also be considered that biochar nutrients are not fully available to plants and may take decades before entering the biological life cycle (European Biochar Certificate [EBC], 2012). For example, the amount of phosphorus available from biochars is only $15 \%, 1 \%$ for nitrogen, and up to $50 \%$ for potassium in the first year (Camps-Arbestain et al., 2015).

According to the results of the chemical characterization of $\mathrm{BS}$ and $\mathrm{BB}$ (Table 1), the transformation of sewage sludge into biochar may be a viable alternative for agricultural use owing to the low levels of trace elements and elimination of pathogenic microorganisms during the pyrolysis process. Similar results were obtained by other authors for biochars from sewage sludge (Wesenbeeck, Prins, Ronsse, \& Antal, 2014).

Generally, except for some elements that are volatile at the pyrolysis temperature, trace elements concentrations in biochars are higher than in the original feedstock owing to volatilization of some compounds. Despite higher concentrations than the original feedstocks, biochar is able to immobilize significant amounts of trace elements in its matrix (Mosa, El-Ghamry, \& Tolba, 2018).

The maximum permitted trace elements values for premium quality grade biochar according to the Swiss Chemical Risk Reduction Act are: $\mathrm{Pb}<120$ $\mathrm{mg} \mathrm{kg}{ }^{-1} ; \mathrm{Cd}<1 \mathrm{mg} \mathrm{kg}^{-1} ; \mathrm{Cu}<100 \mathrm{mg} \mathrm{kg}^{-1} ; \mathrm{Ni}<30$ mg kg${ }^{-1} ; \mathrm{Hg}<1 \mathrm{mg} \mathrm{kg}^{-1} ; \mathrm{Zn}<400 \mathrm{mg} \mathrm{kg}^{-1} ; \mathrm{Cr}<80$ $\mathrm{mg} \mathrm{kg}{ }^{-1}$; and $\mathrm{As}<13 \mathrm{mg} \mathrm{kg}^{-1}$ (EBC, 2012). In the present study, except for copper, BS and BB could be classified as premium quality grade biochar.

Although BS and BB have low concentrations of trace elements, organic contaminants may be present. The thermochemical conversion process used to make biochar can produce polycyclic aromatic hydrocarbons, dioxins, and furans (International Biochar Initiative [IBI], 2012). In this study, the possible organic pollutants associated with the feedstocks and their respective biochars were not evaluated.

The FTIR spectra for BS and BB presented in Figure 2 displayed the transmittance bands in the regions $3018-2993 \mathrm{~cm}^{-1}(\mathrm{C}-\mathrm{H}), 1603 \mathrm{~cm}^{-1}(\mathrm{C}=\mathrm{O})$, and $1021 \mathrm{~cm}^{-1}(\mathrm{C}-\mathrm{O})$ according to the interpretation of Parikh, Goyne, Margenot, Mukome and Calderón (2014) and Silverstein Webster, Kiemle and Bryce (2014). BS showed a considerably larger peak at the $1021 \mathrm{~cm}^{-1}$ band. In contrast to each other, SB showed a band at $3700 \mathrm{~cm}^{-1}$, which may be attributed to N-H or O-H as proposed by Hossain et al. (2011) and at $1423 \mathrm{~cm}^{-1}$ to $\mathrm{C}=\mathrm{C}$, while $\mathrm{BB}$ showed a band around $3480 \mathrm{~cm}^{-1}(\mathrm{O}-\mathrm{H})$ and $1370 \mathrm{~cm}^{-1}$ (aromatic C-O and $\mathrm{C}-\mathrm{H}$ in $\mathrm{CH} 3$ and $\mathrm{CH} 2$ ).

Overall, both biochars contained numerous surface functional groups, which is expected for biochars obtained at relatively low pyrolysis temperature $\left(450{ }^{\circ} \mathrm{C}\right)$. For example, Koetlisi and Muchaonyerwa (2017) showed that biochars produced from latrine waste had N-H functional groups at $350{ }^{\circ} \mathrm{C}\left(3694.07 \mathrm{~cm}^{-1}\right)$ and $550{ }^{\circ} \mathrm{C}$ $\left(3691.69 \mathrm{~cm}^{-1}\right)$ but not at $650{ }^{\circ} \mathrm{C}$. BS was enriched in amino functional groups and comprised $1.8 \% \mathrm{~N}$ (Table 1). SB had peaks at $550-450 \mathrm{~cm}^{-1}$ that can also be an indication of metal-oxides.

At pyrolysis temperatures below $800{ }^{\circ} \mathrm{C}$, the organic phase of biochars generally comprises carbonized organic matter (more aromatic and stable carbon) and non-carbonized organic matter (relatively aliphatic and less stable carbon), which 
may influence their adsorption capacity of metals (Qi et al., 2017b). In this study, biochars were produced at moderate pyrolysis temperatures (450 ${ }^{\circ} \mathrm{C}$ for BS and $350{ }^{\circ} \mathrm{C}$ for $\mathrm{BB}$ ). Thus, BS and BB are constituted by carbonized and non-carbonized organic matter with the capacity to immobilize trace elements.

In the Petri dish tests, the biochar did not present any toxicity to the sorghum seeds and a higher seed germination rate and growth of sorghum seedlings were observed in treatments with biochar addition (Figure 2). Biochar produced from biosolids such as sewage sludge has been reported to contain high concentrations of trace elements and toxic substances (e.g., crystalline silica, dioxin, furans, polyaromatic hydrocarbons, and phenolic compounds) which might reduce the seed germination and seedling growth, with consequent effects on crop establishment and yield (Free, McGill, Rowarth, \& Hedley, 2010). However, these authors did not verify negative effects on seed germination and seedling growth of maize with the use of biochar from sewage sludge.

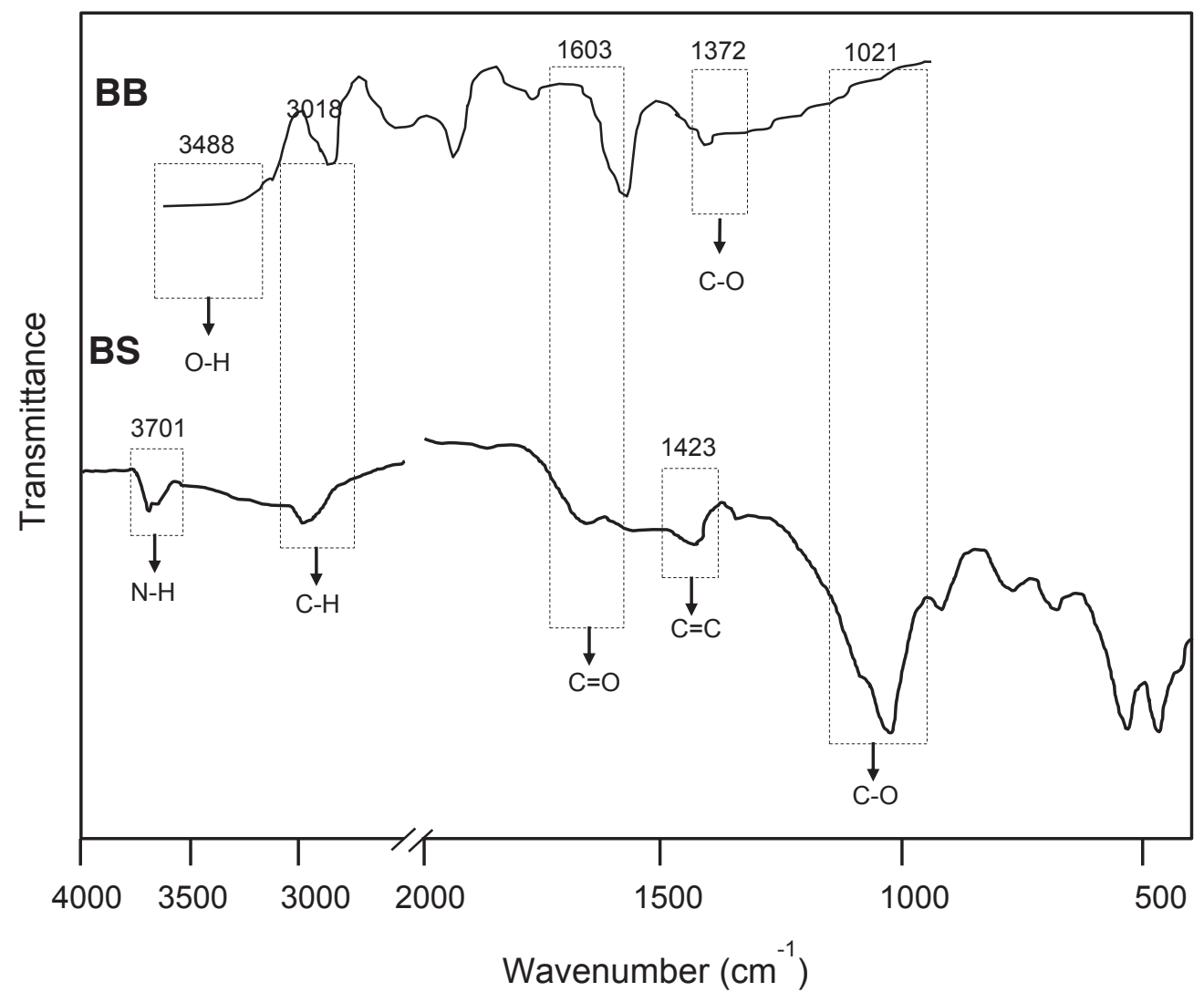

Figure 2. FTIR spectra of sewage sludge biochar (BS) and sugarcane bagasse biochar (BB).

According with Solaiman, Murphy and Abbott, (2012), some compounds in biochars have the potential to either inhibit or stimulate seed germination and seedling growth. These authors verified that small doses of biochar in Petri dishes contributed to the germination of wheat seeds, and recommended Petri dishes bioassay as a rapid and simple preliminary test to identify potential toxicity of biochars on seed germination and early plant growth before biochar application to the soil.

In both Petri dishes and soil, trace elements and nutrients concentrations present in biochars 
influence seed germination and seedling early growth (Gaskin, Steiner, Harris, Das, \& Bibens, 2008). In Petri dish bioassays, inhibition of seed germination or reduced root growth is generally observed at high doses of biochar owing to increasing amounts of trace elements (Thies, Rillig, \& Graber, 2015). In addition, differences between plant species should be considered for biochar application (Solaiman, Murphy, \& Abbott, 2012).
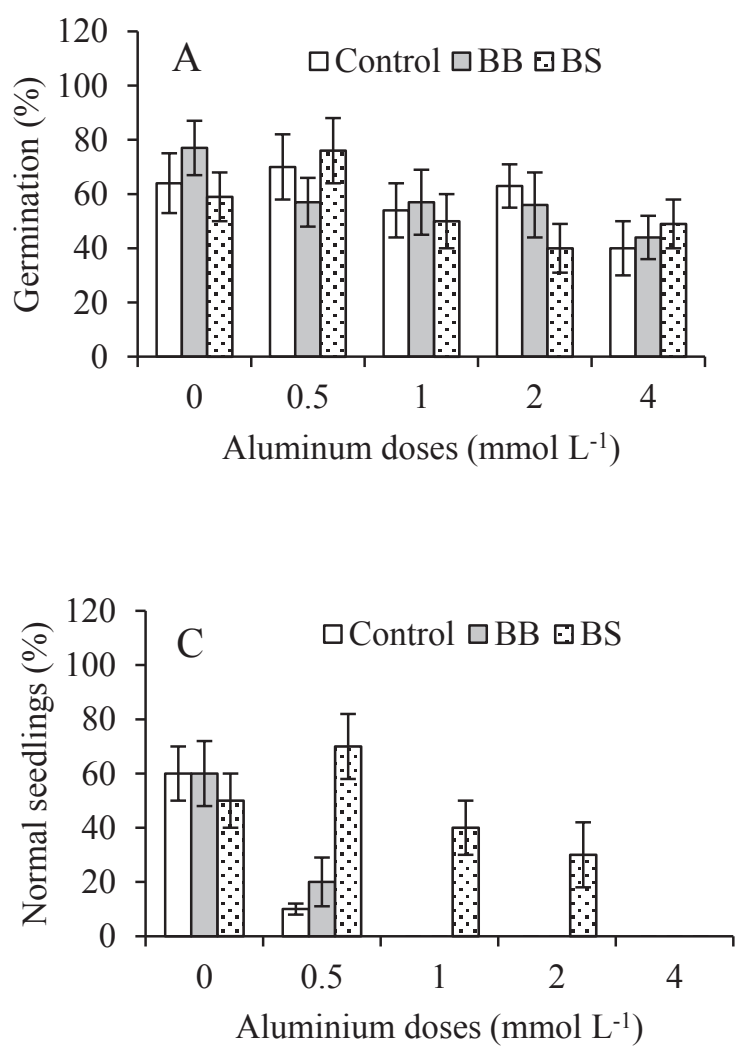

In general, the increase in aluminum (experiment 1) or cadmium doses (experiment 2) decreased sorghum seeds germination. In experiment 1, there were no significant differences between the treatments with biochar addition (BB and BS) and the control treatment (CT) and without aluminum in solution (Figure 3). In contrast, for the cadmium experiment, in the control treatment there was greater seed germination with the addition of BS (Figure 2B).
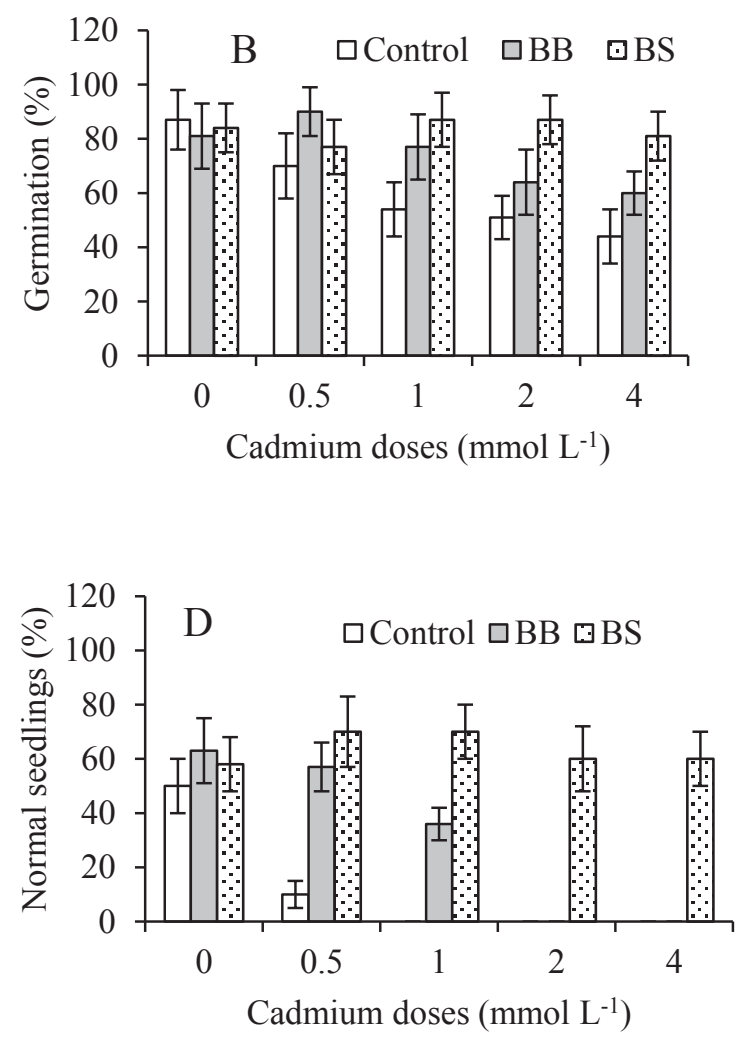

Figure 3. Germination rate of sorghum seeds exposed to doses of aluminum (A) or cadmium (B) without biochar (control) or biochar from sewage sludge (BS) or biochar from sugarcane bagasse (BB). Rate of normal sorghum seedlings exposed to doses of aluminum (C) or cadmium (D) without biochar (control) or BB or BS. Means (vertical bars) and 95\% confidence intervals (solid, capped lines).

There were significant effects of aluminum or cadmium (Figure 3) doses on the percentage of normal seedlings. However, aluminum was more damaging to sorghum seedlings than cadmium and BS was more efficient in mitigating the toxic effects of these elements to the seedlings.
Some hypotheses can possibly explain the effects of biochars on alleviation of aluminum and cadmium toxicity to sorghum seedlings, especially in the treatments with BS, such as increase in the $\mathrm{pH}$ of the medium and adsorption of metals by biochar functional groups. 
The high $\mathrm{pH}$ values of the biochars may have contributed to reducing the more toxic forms of $\mathrm{Al}$ and Cd (Tang et al., 2013), especially with BS which presented higher $\mathrm{pH}$ than $\mathrm{BB}$ (Table 1). With the increase in $\mathrm{pH}, \mathrm{Al}$ and $\mathrm{Cd}$ species were probably altered and consequently reduced the bioavailability and toxicity of these elements to the plants. Qian, Chen and $\mathrm{Hu}$ (2013) investigating the alleviation of aluminum phytotoxicity to wheat plants in a hydroponic system, verified that $\mathrm{Al}^{3+}$ was converted to $\mathrm{Al}(\mathrm{OH})^{2+}, \mathrm{Al}(\mathrm{OH})_{2}{ }^{+}$, and $\mathrm{Al}(\mathrm{OH})_{3}$ owing to the increase in $\mathrm{pH}$ solution by biochar. The monomers $\mathrm{Al}(\mathrm{OH})^{2+}$ and $\mathrm{Al}(\mathrm{OH})_{2}^{+}$were strongly adsorbed by biochar and in addition, these aluminum species were less toxic to the plants than $\mathrm{Al}^{+3}$ (Qian et al., 2013).

Another hypothesis is that the aluminum and cadmium reacted with the functional groups present on the biochar surface forming complexes between the metal and these groups. Different species of aluminum can be absorbed by biochar and this adsorption is dominated by the surface complexation of the carboxyl groups with $\mathrm{Al}(\mathrm{OH})^{2+}$ and $\mathrm{Al}(\mathrm{OH})_{2}^{+}$ (Qian et al., 2013; Tang et al., 2013).

Biochar has been shown to act as an efficient sorbent for various contaminants, such as organic and inorganic, because of its high surface area and special structure and functional groups (Tang et al., 2013). The amphoteric nature of biochar provides acidic and basic functional groups that can adsorb metals (Lehmann \& Joseph, 2015; Uchimiya, Chang, \& Klasson, 2011). The FTIR spectra for BS and BB (Figure 1) showed the occurrence of various functional groups that may have adsorbed both aluminum and cadmium. The mechanisms involved in the adsorption of metals by biochar functional groups are described as faster and weaker interactions accompanied by slower and stronger interactions (Limousin et al., 2007).

Similar to the mechanisms described for alleviating aluminum toxicity, increasing the $\mathrm{pH}$ of the culture medium and adsorption reactions with functional groups may explain the lower toxicity of Cd (Beesley \& Mirmiroli, 2011) to sorghum seedlings in the presence of BS or BB.

The mechanisms described for aluminum and cadmium toxicity alleviation certainly do not act separately. The reactions between the functional groups (e.g., carboxylic, alcohol, and hydroxyl) on the surface of biochars depend on the $\mathrm{pH}$ of the medium (Tang et al., 2013). At a higher $\mathrm{pH}$, more carboxylic groups on the surface of the biochar deprotonate (i.e., $\mathrm{H}+$ ions dissociate), therefore, there are fewer protons in competition for the same sites ( $\mathrm{Lu}$ et al., 2014). In addition, the presence of other elements such as $\mathrm{K}, \mathrm{Na}, \mathrm{Ca}$, and $\mathrm{Mg}$ (Tang et al., 2013; Qi et al., 2017a); surface area; porosity; and surface charge (Li et al., 2017) are involved in the mechanisms of metal immobilization by biochars. Thus, other mechanisms not described in this research may have occurred as suggested by Tang et al. (2013) for sorption of lead by biochar.

The mineral components of biochars, such as calcite $\left(\mathrm{CaCO}_{3}\right)$ and quartz $\left(\mathrm{SiO}_{2}\right)$, can also alleviate the toxicity of metals such as cadmium and aluminum by electrostatic reaction, ion exchange, surface complexation, and formation of metallic precipitates with phosphate, carbonate, and sulfate ions (Li et al., 2017; Zhang, Sun, Yu, \& Sun, 2013; Tsai, Liu, Chen, Chang, \& Tsai, 2012). As seen in Table 1, BS presented higher ash content and therefore, higher content of mineral components in relation to $\mathrm{BB}$. Thus, considering only the mineral components, BS would be more efficient in alleviating cadmium and aluminum toxicity.

In addition to the processes described above, several others mechanisms are used to explain immobilization of metals by biochars, mainly cadmium, generally present in sewage sludge, such as: surface precipitation with minerals (e.g., $\mathrm{PO}_{4}^{3-}$, $\mathrm{CO}_{3}{ }^{2-}$, and $\mathrm{SiO}_{3}{ }^{2-}$ ), surface complexation with functional groups (e.g., $\mathrm{C}=\mathrm{N}$ and $\mathrm{C}-\mathrm{S}$ ), and physical sorption with electrons on biochar's graphene-like structure (e.g., $\mathrm{C}=\mathrm{C}$ and $\mathrm{C} \equiv \mathrm{C}$ ) ( $\mathrm{Li}$ et al., 2017, Tan et al., 2015; Wiedemeier et al., 2015). 
Two main groups of mechanisms explain the tolerance of plants to toxic aluminum; external mechanisms, in which plants release organic acids from the root, usually citrate and malate, that bind to aluminum forming stable complexes and preventing absorption by the plant and internal mechanisms in which aluminum is absorbed by the plant and is inactivated by some enzyme or isolate within the vacuole (George, Horst, \& Neumann, 2012). In the present study, in addition to biochar immobilization of aluminum, some compounds or elements present in the biochar may have favored, for example, aluminum complexation by organic compounds produced by sorghum plants.

The highest values of the shoot and roots dry matter yields of sorghum seedlings were obtained in BS treatments (Figure 4). These results are consistent with those presented in Figure 1. It was also verified that in the treatment without application of $\mathrm{Al}$ or $\mathrm{Cd}$, the highest dry matter yields were obtained when biochar was added to the medium.
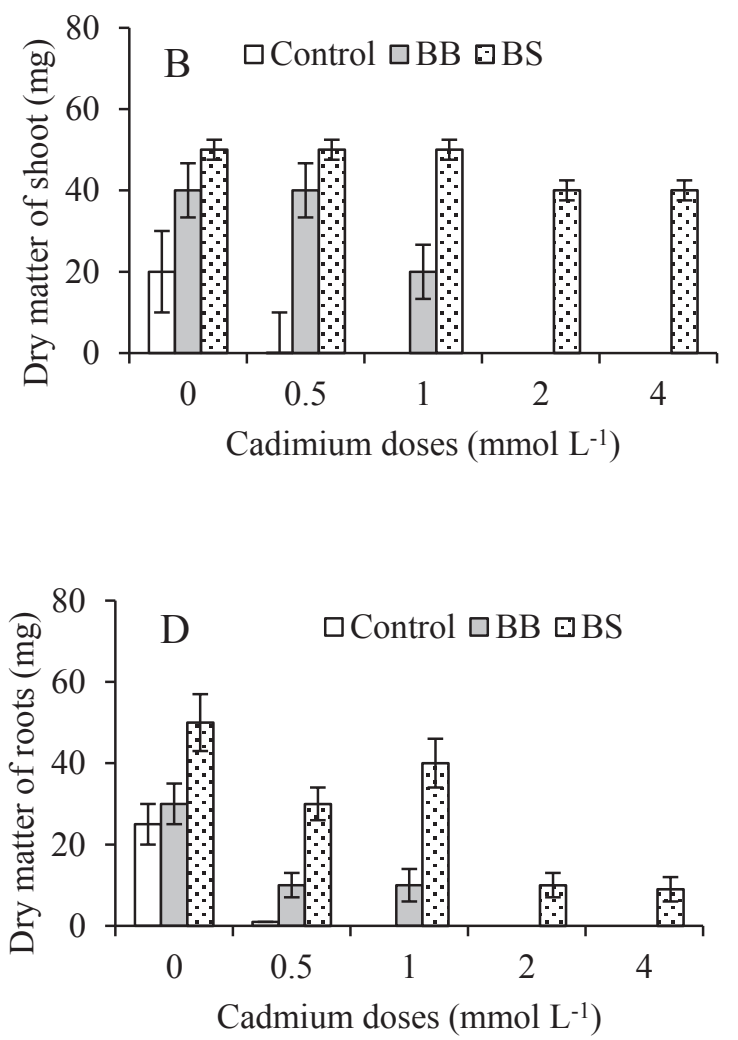

Figure 4. Dry matter of shoot of normal sorghum seedlings exposed to doses of aluminum (A) or cadmium (B) without biochar (control) or biochar from sewage sludge (BS) or biochar from sugarcane bagasse (BB). Dry matter of roots of normal sorghum seedlings exposed to doses of aluminum (C) or cadmium (D) without biochar (control) or BB or BS. Means (vertical bars) and 95\% confidence intervals (solid, capped lines).

As discussed previously, the decrease in aluminum and cadmium toxicity by different mechanisms owing to the addition of biochar explains the higher yields of dry matter by sorghum seedlings in the BS and BB treatments. Other authors working with wheat (Abbas et al., 2017), rice (Rizwan et al., 2016), and sorghum (Soudek et al., 2016) found higher dry matter yield and lower $\mathrm{Cd}$ concentrations in seedlings grown in treatments with biochar, consistent with the results obtained in this study. 
Compared to the limestone and organic sorbents effects, biochar can be a sustainable alternative for the alleviation of soil acidity and metal toxicity. Therefore, the biochar amendment appears to be a novel approach for aluminum detoxification in acidic soils (Qian et al., 2013) and remediation of soils contaminated by trace elements (Penido et al., 2019; Li et al., 2017). In addition to the effects on the immobilization of toxic metals, biochars are sources of nutrients for plants (Table 1) and high levels of zinc present in some biochars may decrease the cadmium uptake by plants through inhibition mechanisms (Rizwan et al., 2016).

The biochars used in this study were non-toxic to plants and contributed to the reduction of aluminum and cadmium toxicity and to the growth and development of sorghum seedlings. The increase in $\mathrm{pH}$ and sorption reactions are mechanisms that can explain the alleviation of the soluble aluminum and cadmium by biochar. Although the presence of dioxin, furans, polyaromatic hydrocarbons, and phenolic compounds has not been evaluated, we believe that the concentration of these compounds, if present in $\mathrm{BS}$ and $\mathrm{BB}$, did not negatively affect seed germination and initial growth of sorghum seedlings.

In addition to using the soil-less Petri dish bioassay as a preliminary ecotoxicological test for biochar screening (Solaiman, Murphy and Abbott, 2012), we recommend this procedure to evaluate the ability of the biochar to reduce aluminum and cadmium toxicity to plants.

\section{Conclusions}

Biochars from sugarcane bagasse and sewage sludge do not present potential for toxicity to sorghum seeds and seedlings. The effects of aluminum and cadmium toxicity are lower when biochar is added to the culture medium. The biochar from sewage sludge is more efficient in alleviating aluminum and cadmium toxicity than the biochar from sugarcane bagasse.

\section{Acknowledgments}

This research was supported by the National Program for Academic Cooperation of the Coordination for the Improvement of Higher Education Personnel (CAPES / Brazil), by the Brazilian National Council for Scientific and Technological Development (CNPq / Brazil) and by the Minas Gerais State Foundation for Research Support (FAPEMIG / Brazil).

\section{References}

Abbas, T., Rizwan, M., Ali, S., Adrees, M., Zia-UrRrehman, M., Qayyum, M. F., Murtaza, G. (2017). Effect of biochar on alleviation of cadmium toxicity in wheat (Triticum aestivum L.) grown on Cdcontaminated saline soil. Environmental Science and Pollution Research, 1(26), 1-13. doi: 10.1007/ s11356-017-8987-4

Abdelhafez A. A., Li, J., Abbas, M. H. H. (2014). Feasibility of biochar manufactured from organic wastes on the stabilization of heavy metals in a metal smelter contaminated soil. Chemosphere,117, 66-71. doi: 10.1016/j.chemosphere.2014.05.086

Ahmad, M., Rajapaksha, A. U., Lim, J. E., Zhang, M., Bolan, N., Mohan, D.,... Ok, Y. S. (2014). Biochar as a sorbent for contaminant management in soil and water: a review. Chemosphere, 99, 19-33. doi: 10.1016/j.chemosphere.2013.10.071

American Society for Testing and Materials. (2013). D1762-84. Standard test method for chemical analysis of wood charcol (Vol. 84, pp.1-2). Retrieved from https://www.astm.org/Standards/D1762.htm

Beesley, L., \& Marmiroli, M. (2011). The immobilisation and retention of soluble arsenic, cadmium and zinc by biochar. Environmental Pollution, 159(2), 474480. doi: 10.1016/j.envpol.2010.10.016

Camps-Arbestain, M., Amonette, J. E., Singh, B., Wang, T., \& Schmidt, H. P. (2015). A biochar classification system and associated test methods. In J. Lehmann, \& S. Joseph (Ed.). Biochar for environmental management (Chap. 8, pp. 165-194). London: Routledge. Retrieved from http://www.css.cornell. edu/faculty/lehmann/publ/First\%20proof\%201301-09.pdf

Chai, Y., Currie, R. J., Davis, J. W., Wilken, M., Martin, J. D., Fishman, V. N., \& Ghosh, U. (2012). Effectiveness of activated carbon and biochar in 
reducing the availability of polychlorinated dibenzo$p$-dioxins/dibenzofurans in soils. Environmental Science \& Technology, 46(2), 1035-1043. doi: 10.1021/es2029697

European Biochar Certificate. (2012). Guidelines for a sustainable production of biochar. Arbaz: European Biochar Foundation. doi: 10.13140/ RG.2.1.4658.7043

Free, H. F., McGill, C. R., Rowarth, J. S., \& Hedley, M. J. (2010). The effect of biochars on maize (Zea mays) germination. New Zealand Journal of Agricultural Research, 53, 1-4. doi: 10.1080/00288231003606039

Gaskin, J. W., Steiner, C., Harris, K., Das, K. C., \& Bibens, B. Effect of low-temperature pyrolysis conditions on biochar for agricultural use. Transactions of the Asabe, 51(6), 2061-2069, 2008. doi: 10.13031/2013.25409

George, E., Horst, W. J., \& Neumann, E. (2012). Adaptation of plants to adverse chemical soil conditions. In P. Marschner (Ed.). Marschner's mineral nutrition of higher plants (3rd ed., Chap. 17, pp. 409-472). London: Academic Press. doi: 10.1016/b978-0-12-384905-2.00017-0

Glaser, B., Lehmann, J., \& Zech, W. (2002). Ameliorating ph ysical and chemical properties of highly weathered soils in the tropics with charcoal: a review. Biology and Fertility of Soils, 35(4), 219-230. doi 10.1007/ s00374-002-0466-4

Gwenzi, W., Chaukura, N., Mukome, F. N. D., Machado, S., \& Nyamasoka, B. (2015). Biochar production and applications in sub-saharan Africa: opportunities, constraints, risks and uncertainties. Journal of Environmental Management, 150, 250-61. doi: 10.1016/j.jenvman.2014.11.027

International Biochar Initiative. (2012). Standardized product definition and product testing guidelines for biochar that is used in soil. Washington: IBI. Retrieved from https://biochar-international.org/

Kim, J., Ok, Y. S., Choi, G., \& Park, B. (2015). Residual perfluorochemicals in the biochar from sewage sludge. Chemosphere, 134, 435-437. doi: 10.1016/j. chemosphere.2015.05.012

Koetlisi, K A, \& Muchaonyerwa P. (2017). Biochar types from latrine waste and sewage sludge differ in physicochemical properties and cadmium adsorption. American Journal of Applied Science, 14(11), 10391048. doi: 10.3844/ajassp.2017.1039.1048

Lee, Y., Park J., Ryu, C., Gang. K. S., Yang, W.; Park. Y. K., Jung J., \& Hyun, S. (2013). Comparison of biochar properties from biomass residues produced by slow pyrolysis at $500^{\circ} \mathrm{C}$. Bioresource Technology, 148, 196-201. doi: 10.1016/j.biortech.2013.08.135

Lehmann, J., \& Joseph, S. (2015). Biochar for environmental management: an introduction. In J. Lehmann \& S. Joseph(Ed.). Biocharforenvironmental management. (2rd ed., pp. 1-4) London: Routledge. Retrieved from http://www.css.cornell.edu/faculty/ lehmann/publ/First\%20proof\%2013-01-09.pdf

Li, H., Dong, X., Silva, E. B., Oliveira, L. M., Chen, Y., \& Ma, L. Q. (2017). Mechanisms of metal sorption by biochars: biochar characteristics and modifications. Chemosphere, 178, 466-478. doi: 10.1016/j.chemosphere.2017.03.072

Limousin, G., Gaudet, J. P., Charlet, L., Szenknect, S., Barthès, V., \& Krimissa, M. (2007). Sorption isotherms: a review on physical bases, modeling and measurement. Applied Geochemistry, 22(2), 249275. doi: 10.1016/j.apgeochem.2006.09.010

Lu, K., Yang, X., Shen, J., Robinson, B., Huang, H., Liu, D.,... Wang, H. (2014). Effect of bamboo and rice straw biochars on the bioavailability of $\mathrm{Cd}, \mathrm{Cu}$, $\mathrm{Pb}$ and $\mathrm{Zn}$ to Sedum plumbizincicola. Agriculture, Ecosystems \& Environment, 191, 124-132. doi: 10.1016/j.agee.2014.04.010

Mosa, H., El-Ghamry, A., \& Tolba, M. (2018). Functionalized biochar derived from heavy metal rich feedstock: phosphate recovery and reusing the exhausted biochar as an enriched soil amendment. Chemosphere, 198, 351-363. doi: 10.1016/j. chemosphere.2018.01.113

Mukherjee, A., Zimmerman, A. R., \& Harris, W. (2011). Surface chemistry variations among a series of laboratory-produced biochars. Geoderma, 163, 247255. doi: 10.1016/j.biortech.2017.07.033

Parikh, S. J., Goyne, K. W., Margenot, A. J., Mukome, F. N. D., \& Calderón, F. J. (2014). Soil chemical insights provided through vibrational spectroscopy. Advances in Agronomy, 126, 1-148. doi: 10.1016/ B978-0-12-800132-5.00001-8

Paz-Ferreiro, J., Nieto, A., Mendez, A., Askeland, M., \& Gasco, G. (2018). Biochar from biosolids pyrolysis: a review. International Journal of Environmental Health Research, 15(5), 1-16. doi: 10.3390/ ijerph15050956

Penido, E. S., Martins, G. C., Mendes, T. B. M., Melo, L. C. A., Guimarães, I. R., \& Guimarães, L. R. (2019). Combining biochar and sewage sludge for immobilization of heavy metals in mining soils. Ecotoxicology and Environmental Safety, 172, 326333. doi: 10.1016/j.ecoenv.2019.01.110 
Qi, F., Kuppusamy, S., Naidu, R., Bolan, N., Ok, Y. S., Lamb, D.,... Wang, H. (2017a). Pyrogenic Carbon and Its Role in Contaminant Immobilization in Soils. Critical Reviews in Environmental Science and Technology, 47(10), 795-876. doi:10.1080/1064338 9.2017 .1328918

Qi, F., Yan, Y., Lamb, D., Naidu, R., Bolan, N., Liu, Y., ... Semple, K. (2017b). Thermal stability of biochar and its effects on cadmium sorption capacity. Bioresource Technology, 246, 48-56. doi: 10.1016/j. biortech.2017.07.033

Qian, L., Chen, B., \& Hu, D. (2013). Effective alleviation of aluminum phytotoxicity by manure-derived biochar. Environmental Science \& Technology, 47(6), 2737-2745. doi: 10.1021/es3047872

Rajkovichc, S., Enders, A., Hanley, K., Hyland, C., Zimmerman, A. R., \& Lehmann, J. (2012). Corn growth and nitrogen nutrition after additions of biochars with varying properties to a temperate soil. Biology and Fertility of Soils 48(3), 271-284. doi: 10.1007/s00374-011-0624-7

Resolução $N^{o}$ 375, de 29 de agosto de 2006. Define critérios e procedimentos, para o uso agrícola de lodos de esgoto gerados em estações de tratamento de esgoto sanitário e seus produtos derivados, e dá outras providências. Brasília, Brasil. 2006. Retirado de http://www2.mma.gov.br/port/conama/res/res06/ res37506.pdf.

Rizwan, M., Ali, S., Qayyum, M. F., Ibrahim, M., Ziaur-Rehman, M, Abbas, T., \& Ok, Y. S. (2016). Mechanisms of biochar-mediated alleviation of toxicity of trace elements in plants: a critical review. Environmental Science and Pollution Research, 23(3), 2230-2248. doi: 10.1007/s11356-015-5697-7

Samac, D. A., \& Tesfaye, M. (2003). Plant improvement for resistance to aluminum in acid soils-a review. Plant Cell, Tissue and Organ Culture,75(3), 189207. doi: $10.1023 / \mathrm{A}: 1025843829545$

Silva, I. C. B., Basílio, J. J. N., Fernandes, L. A., Colen, F., Sampaio, R. A., \& Frazão, L. A. (2017). Biochar from different residues on soil properties and common bean production. Scientia Agricola, 74(5), 378-382. doi: 10.1590/1678-992x-2016-0242

Silverstein, R. M., Webster, F. X., Kiemle, D. J., \& Bryce, D. L. (2014). Spectrometric identification of organic compounds (8th ed.). New York: John Wiley \& Sons, Inc.

Solaiman, Z. M., Murphy, D. V., \& Abbott, L. K. (2012). Biochars influence seed germination and early growth of seedlings. Plant and Soil, 353(1-2), 273287. doi: 10.1007/s11104-011-1031-4

Soudek, P., Petrová, S., Vaňková, R., Song, J., \& Vaněk, T. (2014). Accumulation of heavy metals using Sorghum sp. Chemosphere, 104, 15-24. doi: 10.1016/j.chemosphere.2013.09.079

Soudek, P., Rodriguez Valesca, I.M., Petrová, Š., Song, J., \& Vaněk, T. (2016). Characteristics of different types of biochar and effects on the toxicity of heavy metals to germinating sorghum seeds. Journal of Geochemical Exploration, 182, 157-165. doi: 10.1016/j.gexplo.2016.12.013

Steenari, B. M., Karlsson, L. G., \& Lindqvist, O. (1999). Evaluation of the leaching characteristics of wood ash and the influence of ash agglomeration. Biomass and Bioenergy, 16(2), 119-136. doi: 10.1016/S09619534(98)00070-1

Tan, X., Liu, Y., Zeng, G., Wang, X., Hu, X., Gu, W., \& Yang, Z. (2015). Application of biochar for the kemoval of pollutants from aqueous solutions. Chemosphere, 125, 70-85. doi: 10.1016/j. chemosphere.2014.12.058

Tang, J., Zhu, W., Kookana, R., \& Katayama, A. (2013). Characteristics of biochar and its application in remediation of contaminated soil. Journal of Bioscience and Bioengineering, 116(6), 653-659. doi: 10.1016/j.jbiosc.2013.05.035

Thies, J. E., Rillig, M. C. \& Graber, E. R. (2015). Biochar Effects on the Abundance, Activity and Diversity of the Soil Biota. In: J. Lehmann, \& S. Joseph (Ed.). Biochar for environmental management (Chap. 13, pp. 327-390). London: Routledge. Retrieved from http://www.css.cornell.edu/faculty/lehmann/publ/ First\%20proof\%2013-01-09.pdf

Tsai, W. T., Liu, S. C., Chen, H. R., Chang, Y. M., \& Tsai, Y. L. (2012). Textural and chemical properties of swinemanure-derived biochar pertinent to its potential use as a soil amendment. Chemosphere, 89(2), 198-203, doi: 10.1016/j.chemosphere.2012.05.085

Uchimiya, M., Chang, S., \& Klasson, K. T. (2011). Screening biochars for heavy metal retention in soil: role of oxygen functional groups. Journal of Hazardous Materials, 190(1-3), 432-442. doi: 10.1016/j.jhazmat.2011.03.063

United States Environmental Protection Agency. (1996). Method 3050B: acid digestion of sediments, sludges, and soils. Washington: USEPA. (Revision 2). Retrieved from https://www.epa.gov/esam/epamethod-3050b-acid-digestion-sediments-sludgesand-soils 
Waqas, M., Li, G.; Khan, S., Shamshad, I.; Reid, B. J., Qamar Z., \& Chao, C. (2015). Application of sewage sludge and sewage sludge biochar to reduce polycyclic aromatic hydrocarbons (PAH) and potentially toxic elements (PTE) accumulation in tomato. Environmental Science and Pollution Research, 22(16), 12114-12123. doi: 10.1007/ s11356-015-4432-8

Wesenbeeck, V. V., Prins, W., Ronsse, F., \& Antal, M. J., Jr. (2014). Sewage sludge carbonization forbiochar applications. Fate of heavy metals. Energy \& Fuels, 28(8), 5318-5326. doi: 10.1021/ef500875c
Wiedemeier, D. B., Abiven, S., Hockaday, W. C, Keiluweit, M., Kleber, M., Masiello, C.A.,... Schmidt, M. W. I. (2015). Aromaticity and degree of aromatic condensation of char. Organic Geochemistry, 78, 135-143. doi: 10.1016/j.orggeochem.2014.10.002

Zhang, P., Sun, H., Yu, L., \& Sun, T. (2013). Adsorption and catalytic hydrolysis of carbaryl and atrazine on pig manure-derived biochars: impact of structural properties of biochars. Journal of Hazardous Materials, 244-245, 217-224. doi: 10.1016/j. jhazmat.2012.11.046 
